\title{
PRIMARY SCHOOL TEACHERS' OPINIONS ABOUT THE CURRICULAR DOCUMENTS USED FOR STUDYING THE MATHEMATICS AND ENVIRONMENTAL EXPLORATION SUBJECT
}

\author{
IOANA-CRISTINA MAGDAȘ \\ Babeş-Bolyai University, Faculty of Psychology and Sciences of Education, Department of Exact Sciences \\ Didactics, Cluj-Napoca, Romania, e-mail: ioana_magdas@yahoo.com
}

\section{MARIA ELIZA DULAMĂ}

Babeş-Bolyai University, Faculty of Psychology and Sciences of Education, Department of Exact Sciences Didactics, Cluj-Napoca, Romania, e-mail: dulama@upcmail.ro

\section{OANA-RAMONA ILOVAN}

Babeş-Bolyai University, Faculty of Geography, Department of Regional Geography and Territorial Planning, Cluj-Napoca, Romania, e-mail: ilovanoana@yahoo.com

\section{IOANA CAMELIA CRIȘAN}

"Nicolae Bălcescu" Theoretical High School, Cluj-Napoca, Romania, e-mail: crisan_cml@yahoo.com

(Received: July 2017; in revised form: August 2017)

\begin{abstract}
Due to the introduction in 2013 into the new Framework Plan for the primary education of the integrated Mathematics and Environmental Exploration (MEE) subject, of new textbooks and auxiliaries, we considered it necessary to find the the teachers' opinions regarding the way in which the curriculum documents facilitate the study of the MEE subject. The present article is based on a research performed using a survey carried out voluntarily and anonymously by 131 teachers for primary education. Through the responses to the questionnaire, we identified several important issues. Regarding teachers' sources of documentation, we found out that they prefered online sources (websites, blogs) and specialized forums, which was surprising because these sources did not have the reliability of correct information. Only on the next places were placed the official documents or those elaborated by specialists. Teachers assigned scores of about four (out of a maximum of five) to the clarity of all components of the school curriculum. In terms of textbooks and auxiliaries, respondents scored better auxiliaries across all the indicators considered. The biggest benefit of introducing the MEE subject identified by
\end{abstract}


respondents was that activities were more attractive or motivating for learning. At the opposite end, the smallest benefits related to ensuring the rigour and learning durability of both Mathematics and Environmental Exploration. Regarding the limitations, disadvantages or problems of studying the MEE subject, the lack of support materials was the first reported by the respondents. On the next places were placed the need for specific lessons with mathematical content or the heavy design of thematic units and lessons.

Keywords: integrated teaching, primary education, curriculum auxiliaries, school curricula, school textbooks

\section{INTRODUCTION}

In 2012, in Romania, it was approved the Framework Plan for Primary Education, the Preparatory Grade, the First and Second Grades. An important change was the introduction of the Mathematics and Environmental Exploration (MEE) subject. Starting from this document and from the provisions of the National Education Law (2011), the curriculum of the MEE subject was developed according to a new competence-based curricular design (M.E.N., 2013). The curriculum was analysed in the literature (Dulamă and Magdaş, 2014).

For studying the MEE subject in the primary education, there are several textbooks for each class, which can be consulted in digital and printed format and downloaded in printed format from the Ministry of National Education, the National Evaluation and Examination Centre site (https://www.manual.edu.ro/). Publishing houses that produce textbooks offer curricular auxiliaries, which are correlated with textbooks, and often provide teachers with thematic activities projects, which facilitate the better study of MEE subject (Dulamă, 2011, 2012).

Even though the official documents in Romania do not have all the information necessary for the integrated study of the MEE (Dulamă and Magdaş, 2014), there are some theoretical information and methodological suggestions in the specialized papers (Dulamă, 2011, 2012; Magdaş, 2014), because the Romanian researchers have been concerned with investigating the integrated study of MEE in the primary education. Other studies focused on the pupils' competences to design the didactic activities at MEE (Dulamă et al., 2015), on teachers' opinions on digital textbooks (Magdaș and Drângu, 2016) and on teachers' training in the primary school for teaching MEE (Magdaş et al., 2017).

The present article is based on research performed using a survey which aimed to identify and analyse the primary school teachers' opinions on how the curricular documents facilitated the study of the MEE subject. 
PRIMARY SCHOOL TEACHERS' OPINIONS ABOUT THE CURRICULAR DOCUMENTS ...

METHOD

Methods and research instruments. We collected data using the survey method. Using a Google Forms questionnaire from Google Drive, we collected the primary school teachers' opinions about their training for the integrated study of the MEE subject and about their training needs (Magdaş et al., 2017) and about the way in which the curriculum documents facilitated the study of the MEE subject. In this paper, we analyse the primary education teachers' answers, expressed during the questionnaire survey, regarding the curricular documents. The questionnaire contained nine items requiring them to choose an answer on a five point Likert scale, with values from 1 to 5 . In March 2017, we distributed the questionnaire to the Facebook social network and by e-mail. We processed the collected data statistically and we represented the results using charts in the Excel programme.

Participants. 131 teachers for primary education filled in the questionnaire voluntarily and anonymously. The respondents belong to different categories based on some criteria. Regarding their educational level, $64.2 \%$ of the teachers have a Bachelor's Degree, $32.1 \%$ of them have a Master's Degree, and $1.5 \%$ (2 respondents) have a Ph.D. Just $2.3 \%$ graduated only a Pedagogical High School. Regarding the didactic degrees (which are stages of the teaching career), more than three quarters (77.1\%) of the respondents have the first didactic degree (which is the highest), $10.7 \%$ have the second didactic degree, $7.6 \%$ of them have the definitive didactic degree, while $4.6 \%$ of them are debutants.

Related to the years of teaching experience, $61.8 \%$ of the respondents have over 20 years in teaching, $23.7 \%$ have between 11 to 20 years, 9.9\% have between 5 to 10 years teaching experience, and only $4.6 \%$ have under 5 years teaching experience. Regarding the school where respondents teach, $64.1 \%$ of them work in urban area schools and $35.9 \%$ in rural area ones. Respondents have the qualification and the didactic experience that allows them to make pertinent assessments of the issues investigated through the questionnaire.

\section{RESULTS AND DISCUSSIONS}

Teachers working in primary education in Romania differentiate by their initial training (Pedagogical high school, Bachelor Degree in Primary and Preschool Education Pedagogy, M.Sc. Degree, Ph.D. in Education Sciences, etc.) and by the years of teaching experience. Therefore, not all of them obtained information about integrating MEE contents during these studies (Magdaş et al., 2017). 
Due to the introduction, in 2013, into the new Framework Plan for the Primary Education of the integrated Mathematics and Environmental Exploration (MEE) subject, we considered it necessary to find the main sources teachers read. From the analysis of these sources on the integration of the MEE content into didactic activities (Figure 1), the most important were the online ones (e.g. websites, blogs) and the specialised forums. This is surprising because these sources are not very reliable in what the correctness of information is concerned. Only on the following places are situated the official documents or those elaborated by didacticians, by groups of authors with experience in teaching (inspectors and teachers for primary education) or by specialists in Educational Sciences.

Didactics of Mathematics books (average 3.51) were perceived differently by teachers than the books of Didactics of Geography (average 2.64) as sources of information on the integration of MEE. This perception is explicable as Mathematics has many exercises related to environmental components, while in Geography, a small part of the content requires mathematical tools and concepts. Teachers considered that they had found little explanatory information about integrating the MEE into school curricula and other official documents, although these should have been the main sources. Pedagogy books and the Didactics of Exact Sciences also provided little information on this subject.

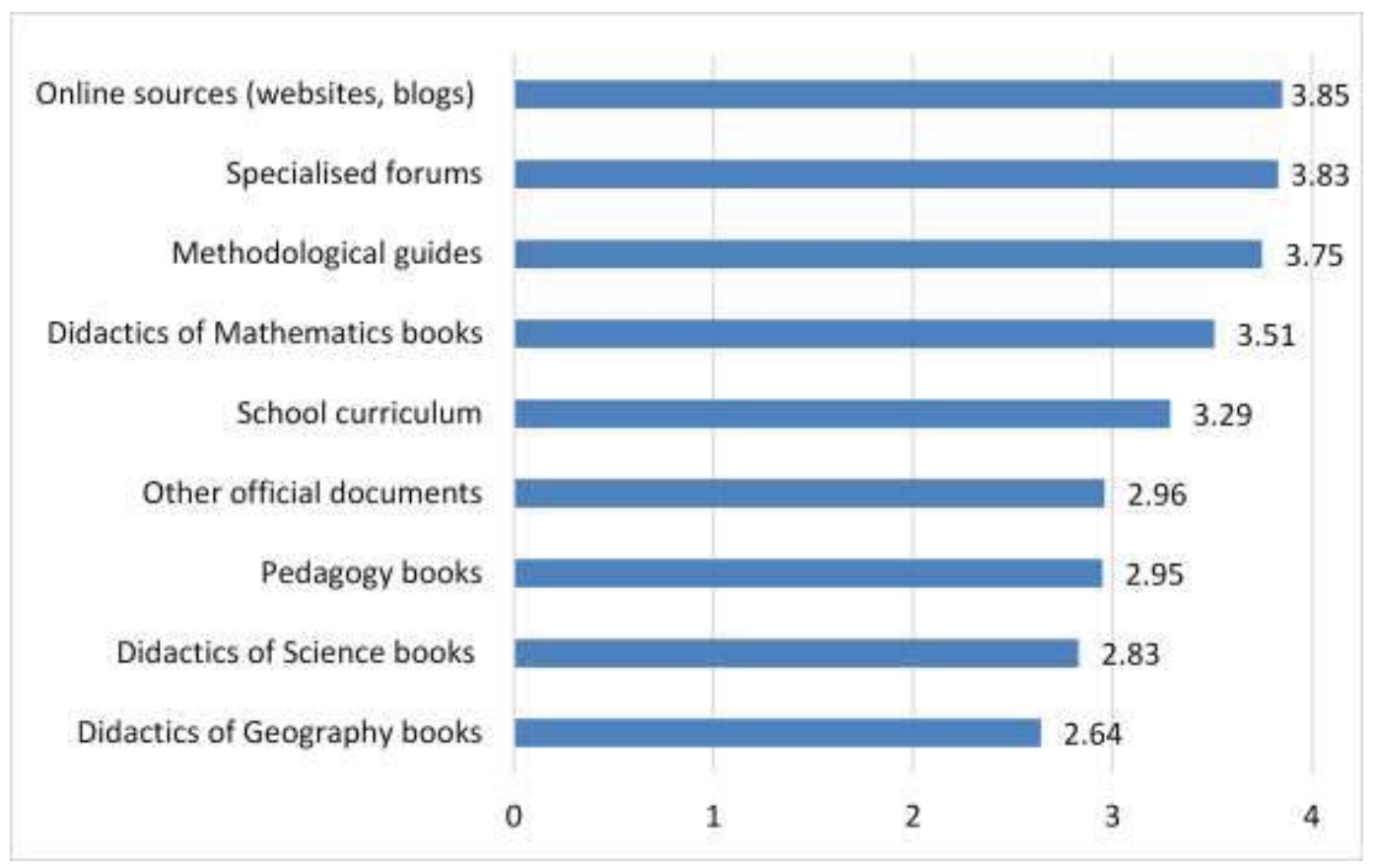

Fig. 1. The sources that teachers used regarding the integration of MEE 
In order to identify the extent to which curriculum provisions were clear to primary school teachers, we asked them to give their opinion on the components of the curriculum. Respondents considered them "largely" clear (around the average 4 - Figure 2), but also pointed out the need to complete them with some information. The methodological suggestions were on the last place, these being considered by teachers to be the least clear, therefore, in order to increase the efficiency of the learning activity, school curricula should be improved in this direction.

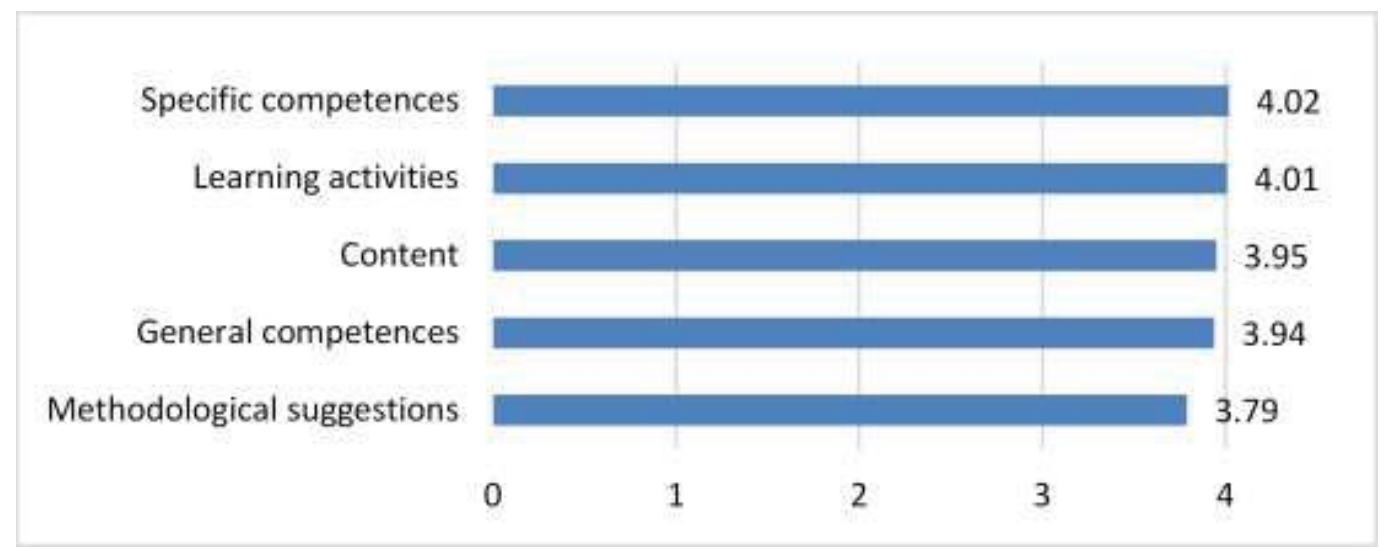

Fig. 2. Level of clarity of the MEE subject curriculum

In Romania, on the site of the Ministry of National Education, the National Evaluation and Examination Centre https://www.manuale.edu.ro/, there are posted the MEE textbooks for the preparatory grade, for the $1^{\text {st }}$, and for the $2^{\text {nd }}$ grade. We posed the problem how well the integration of the MEE contents into these textbooks and auxiliaries was made to be useful to teachers and pupils.

In Table 1, we centralized the percentage of teachers who appreciated the usefulness of textbooks for some indicators, on the one hand, to a very low or low measure, and, on the other hand, to a high or very high measure. Thus, the indicator to which textbooks and auxiliaries least help teachers seemed to be the time management that should be alloted to environmental exploration. Approximately half of the teachers $(49.6 \%$ to $53.9 \%)$ considered auxiliaries to be of great help to the integrated design, to the development of activities, but also to the assessment or to the training of the competences provided in the curriculum. For the same indicators, the percentages for the textbook were lower and lied between $41.1 \%$ and $44.6 \%$.

The textbooks and auxiliaries were assessed as being average useful (textbooks having scores ranging from 3.37 to 2.82 and auxiliaries between 3.47 and 3.10) (Figure 3). The fact that at each indicator the auxiliaries 
were assessed as more useful underlined that auxiliaries had better quality than textbooks, probably because of the predominance of practical activities. The most useful were both textbooks and auxiliaries in the integrated deployment of learning activities at the MEE, in the integrated design of these activities, and in forming and developing of general and specific MEE subject competences provided in the curriculum. Textbooks and auxiliaries were the least useful in managing the time that should have been alloted to Environmental Exploration, probably because these activities should have taken place outside the classroom.

Table 1. The usefulness of MEE textbooks and auxiliaries

\begin{tabular}{|c|c|c|c|c|}
\hline \multirow[t]{2}{*}{ Indicators } & \multicolumn{2}{|c|}{$\begin{array}{l}\text { Very low or low } \\
\text { (\% of respondents) }\end{array}$} & \multicolumn{2}{|c|}{$\begin{array}{l}\text { High or very high } \\
\text { (\% of respondents) }\end{array}$} \\
\hline & textbooks & auxiliaries & textbooks & auxiliaries \\
\hline $\begin{array}{l}\text { Integrated design of learning } \\
\text { activities at MEE subject }\end{array}$ & 23.4 & 21.2 & 44.6 & 52.2 \\
\hline $\begin{array}{l}\text { Developing integrated MEE } \\
\text { learning activities }\end{array}$ & 21.3 & 19.5 & 46.4 & 53.9 \\
\hline $\begin{array}{l}\text { Managing time that should } \\
\text { be alloted to Mathematics }\end{array}$ & 28.2 & 27.8 & 32.5 & 44.4 \\
\hline $\begin{array}{l}\text { Managing time that should } \\
\text { be alloted to Environmental } \\
\text { Exploration }\end{array}$ & 39.4 & 30.7 & 27.5 & 40.9 \\
\hline $\begin{array}{l}\text { Pupils' acquirement of } \\
\text { specific Mathematics notions }\end{array}$ & 28.5 & 21.6 & 42.9 & 47.2 \\
\hline $\begin{array}{l}\text { Pupils' acquirement of } \\
\text { specific Environmental } \\
\text { Exploration notions }\end{array}$ & 32.3 & 22.8 & 35.4 & 44.9 \\
\hline $\begin{array}{l}\text { Pupils' acquirement of } \\
\text { integrated knowledge } \\
\text { specific to Mathematics and } \\
\text { Environmental Exploration }\end{array}$ & 29.7 & 22.0 & 35.1 & 44.9 \\
\hline $\begin{array}{l}\text { Training and development of } \\
\text { general and specific MEE } \\
\text { subject competences } \\
\text { provided in the curriculum }\end{array}$ & 23.2 & 21.6 & 41.1 & 49.6 \\
\hline $\begin{array}{l}\text { Integrated assessment of } \\
\text { knowledge and competences } \\
\text { specific to Mathematics and } \\
\text { Environmental Exploration }\end{array}$ & 27 & 19.8 & 41.3 & 50 \\
\hline
\end{tabular}


PRIMARY SCHOOL TEACHERS' OPINIONS ABOUT THE CURRICULAR DOCUMENTS ...

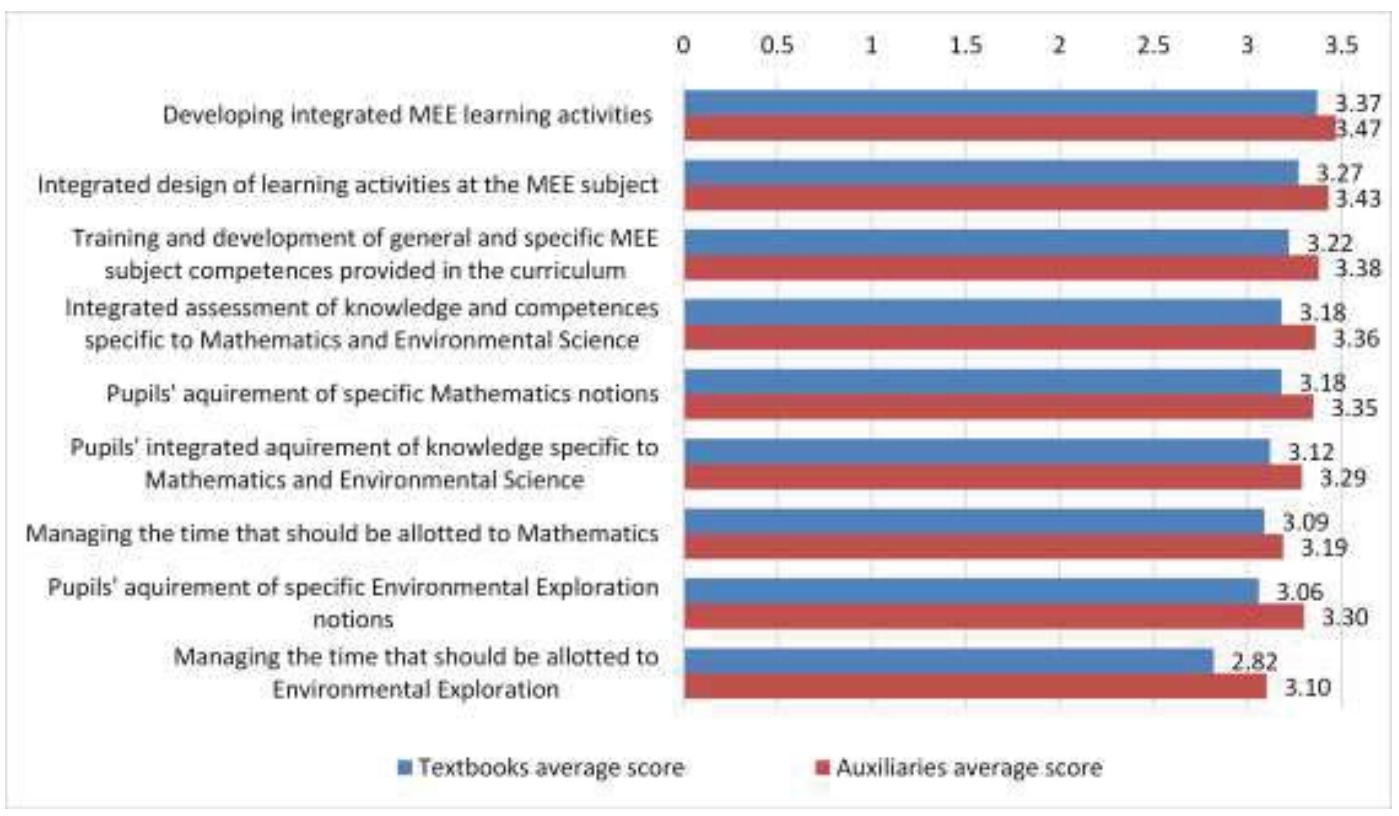

Fig. 3. The usefulness of MEE textbooks and auxiliaries

For an analysis of the quality and effectiveness of learning activities in school textbooks, we suggested to the respondents to determine to what extent they facilitated or provided certain aspects of learning. In Table 2, we centralized to what extent teachers appreciated the usefulness of textbooks according to some indicators on the one hand, in a very low or low measure, and on the other hand in a high or very high measure.

Many respondents considered attractive and motivating for learning, in a high or very high measure, both learning activities included in curriculum auxiliaries (51.6\%) and in textbooks (over $44 \%$ ). At the same time, more than $40 \%$ of the teachers believed that the learning activities of the two types of materials facilitated much or very much the learning of Mathematics and of Environmental Exploration and ensured the scientific rigour necessary for Mathematics and Environmental Science.

On the opposite side, we noticed that over $34 \%$ of the respondents believed that learning activities facilitated in a very low or low measure the holistic understanding of reality. Nearly one third of the respondents considered that textbooks ensured in a very low or low measure the learning durability of both Mathematics (30.9\%) and Environmental Exploration (33\%). This situation appeared probably because of to the small number of exercises for fixing knowledge or of the difficulty of the topics proposed for study, which exceeded the pupils' level of understanding at that age. 
Table 2. The importance of learning activities in MEE textbooks and curricular auxiliaries

\begin{tabular}{|c|c|c|c|c|}
\hline \multirow[t]{2}{*}{ Indicators } & \multicolumn{2}{|c|}{$\begin{array}{l}\text { Very low or low } \\
\text { (\% of respondents) }\end{array}$} & \multicolumn{2}{|c|}{$\begin{array}{l}\text { High or very high } \\
\text { (\% of respondents) }\end{array}$} \\
\hline & textbooks & auxiliaries & textbooks & auxiliaries \\
\hline $\begin{array}{l}\text { Facilitating correlation of } \\
\text { mathematical knowledge in daily } \\
\text { contexts }\end{array}$ & 28.7 & 19.4 & 40.3 & 50.4 \\
\hline $\begin{array}{l}\text { Facilitating Environmental } \\
\text { Exploration in daily contexts }\end{array}$ & 29.7 & 24.1 & 36.7 & 45.7 \\
\hline $\begin{array}{l}\text { Facilitating a holistic } \\
\text { understanding of reality }\end{array}$ & 34.4 & 27.3 & 35.1 & 42.2 \\
\hline $\begin{array}{l}\text { Ensuring the necessary scientific } \\
\text { rigour for Mathematics }\end{array}$ & 29.9 & 22.7 & 41.1 & 46.8 \\
\hline $\begin{array}{l}\text { Ensuring the necessary scientific } \\
\text { rigour for Environmental Science }\end{array}$ & 30.7 & 25.8 & 39.4 & 43.7 \\
\hline $\begin{array}{l}\text { Facilitating learning of } \\
\text { Mathematics }\end{array}$ & 24.0 & 20.1 & 42.4 & 52.4 \\
\hline $\begin{array}{l}\text { Facilitating Environmental } \\
\text { Exploration }\end{array}$ & 27.6 & 22.2 & 42.5 & 46.0 \\
\hline $\begin{array}{l}\text { Ensuring the durability of } \\
\text { Mathematics knowledge }\end{array}$ & 30.9 & 18.4 & 35.7 & 42.4 \\
\hline $\begin{array}{l}\text { Ensuring the durability of } \\
\text { Environmental Exploration } \\
\text { knowledge }\end{array}$ & 32.8 & 24.6 & 35.2 & 40.5 \\
\hline $\begin{array}{l}\text { Attractive / motivating for } \\
\text { learning }\end{array}$ & 29.7 & 19.5 & 44.1 & 51.6 \\
\hline
\end{tabular}

The learning activities within textbooks facilitated the learning of Mathematics (average score of 3.29), of Environmental Exploration (average score of 3.18) and provided the necessary scientific rigour for Mathematics (average score of 3.16). Unlike textbooks, curricular auxiliaries facilitated more Mathematics learning (average score of 3.43), correlation of mathematical knowledge in daily contexts (average score of 3.39), ensured the durability of Mathematics knowledge (average score of 3.32), and were appreciated as attractive / motivating for learning (average score of 3.38). Overall, the learning activities facilitated or provided the learning context through curriculum auxiliaries with scores between 3.17 and 3.43, while through textbooks with average scores between 2.99 and 3.29 (Figure 4). We noticed that at each indicator the auxiliaries obtained a better score, probably due to the predominance of the practical activities within them. 
PRIMARY SCHOOL TEACHERS' OPINIONS ABOUT THE CURRICULAR DOCUMENTS ...

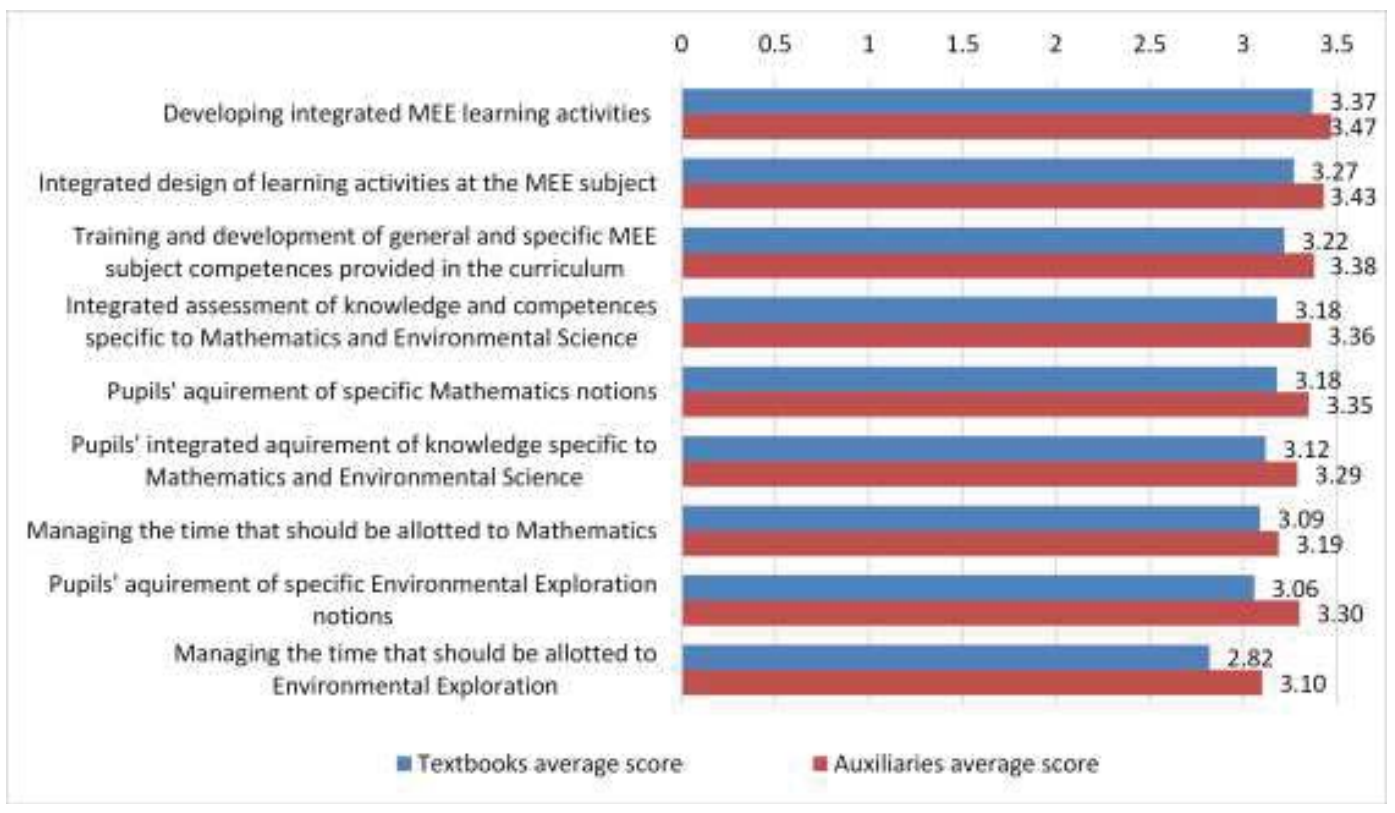

Fig. 4. The importance of learning activities in MEE textbooks and curricular auxiliaries

In the hierarchy of the types of MEE activities (Figure 5), on the first places were those in which there was a significant integration of the Mathematics, Environmental Science and Geography contents. On the first place were fixing knowledge activities through real-life problems and / or with other subjects that rather indicated an exemplificative route. The second place belonged to the activities where the students should have used the MEE knowledge, which indicated an applicative learning mode that provided the connexion between theory and practice. Projects were ranked third in the hierarchy of activities, followed by the way in which the lessons order observed the textbook.

Teachers used less the approach in which learning had an investigative character, involving learning by discovery (average score of 3.39). The activities in which Mathematics lessons alternated with those of Environment Exploration with a lower degree of content integration were placed on the last places in the hierarchy. Although in some MEE textbooks there was an alternation of 3-4 lessons of Mathematics and one of Environmental Exploration, however, the results indicated that such way of organising the activity was less used by teachers (average score of 3.11). The least used was to allot for several weeks hours only for Mathematics, then over a week do only Environmental Exploration activities. 
I.-C. MAGDAȘ, M. E. DULAMĂ, O.-R. ILOVAN, I.C. CRIȘAN

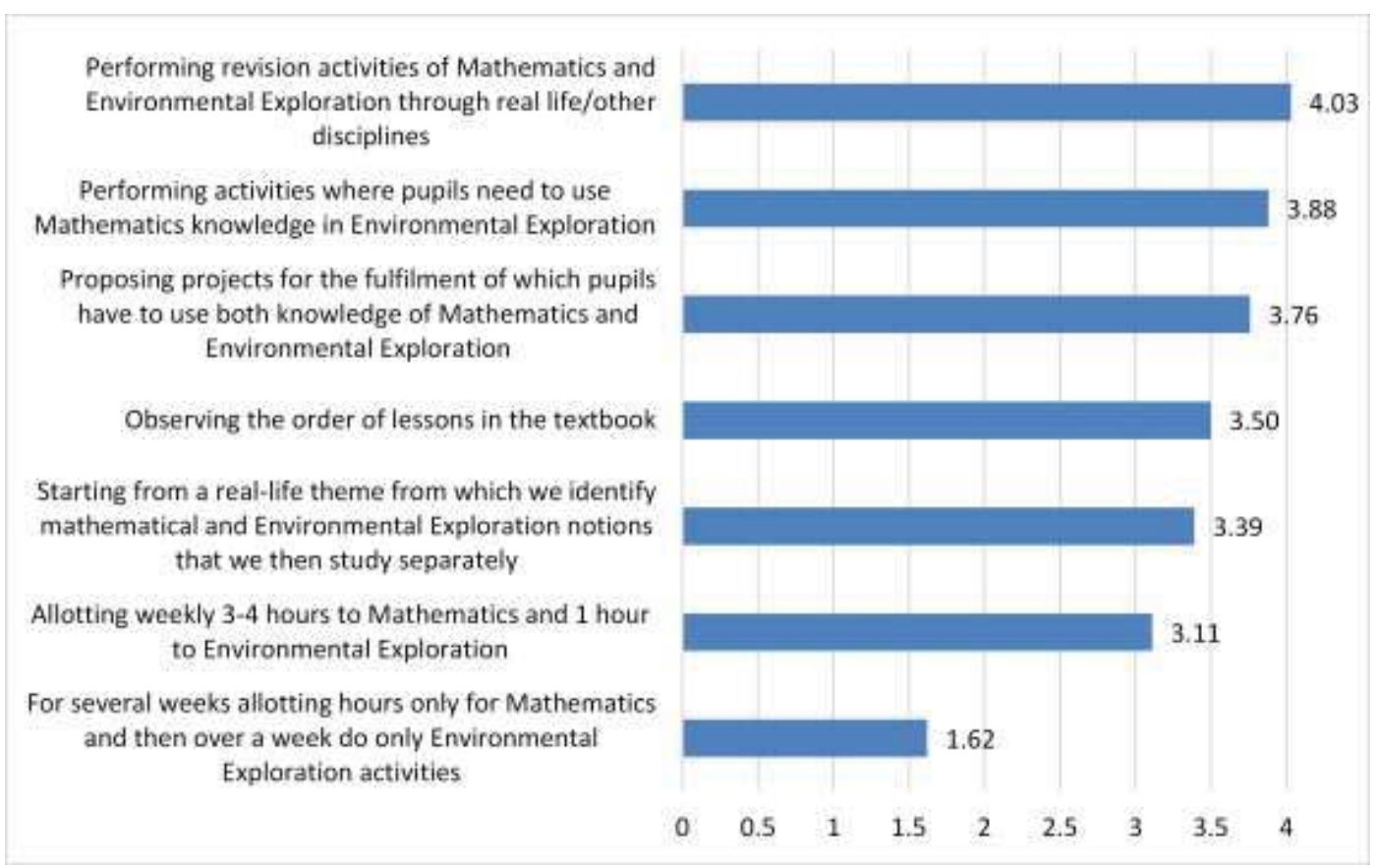

Fig. 5. Ways to organise activities at the MEE subject

Analysing the percentage of teachers doing each type of activity from very rarely to very often (Figure 6 ), we had the following results. Very often or often $71.9 \%$, respectively $59.7 \%$ of the teachers proposed real life problem solving, respectively projects in which they needed to use knowledge of Mathematics and Environmental Science / Geography. This frequency is also explained by the fact that the design of activities in the primary education is carried out on thematic units containing content from all subjects (Dulamă, 2011, 2012), and these thematic units can sometimes be perceived as thematic projects.

Very often or often $55.2 \%$ of teachers followed the order of lessons in the MEE textbook. Even more than two-thirds of the teachers (66.5\%) very often or often organized activities where knowledge of both areas was required. However, less than half of the teachers $(43.9 \%)$ very often or often alloted 3-4 hours per week to Math and 1 hour to Environmental Exploration, which showed that teachers adapted the curriculum requirements to the pupils' needs. 


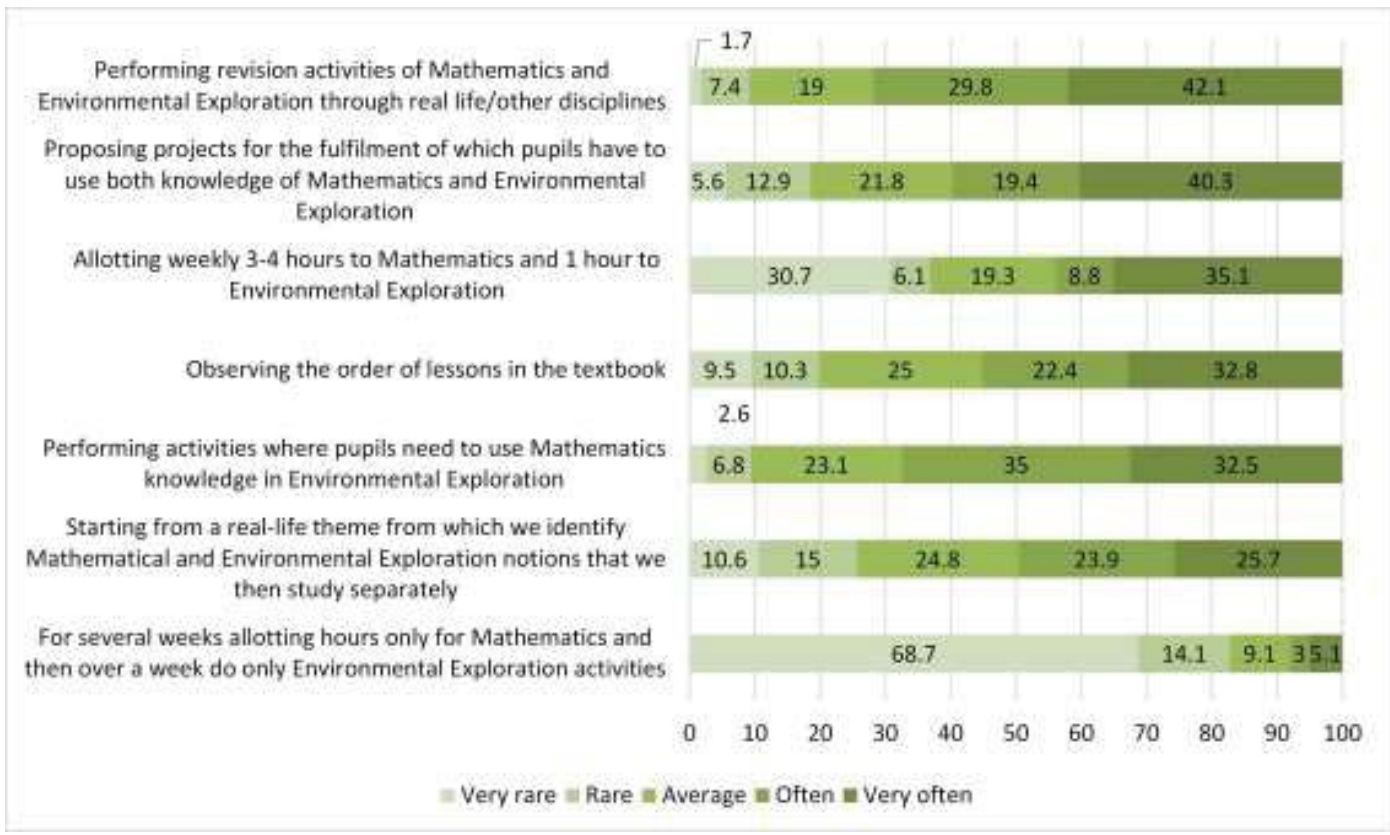

Fig. 6. Frequency of organising activities at the MEE subject

In the MEE curriculum for the preparatory grade, for the first grade and for the second grade (2013), the decision to integrate the two disciplines is supported. We were interested in the extent to which arguments corresponded to the teachers' opinions, based on the experience gained in the didactic activity carried out. In Figure 7, one can notice that all the benefits / advantages got scores above the average, which was a positive aspect. The greatest benefit of integrating MEE was that activities were attractive / motivating for learning, perception explained by the curriculum recommendation (2013) that the predominant activity in these classes to be the game, similar to the kindergarten activity.

The last place among benefits / advantages belonged to ensuring the scientific rigour necessary for Mathematics, so that could be considered rather a weakness of the integration of MEE. The second and third place belonged to enabling the correlation of Mathematical and Environmental Exploration in everyday contexts, but that relationship of knowledge accumulated in school with that in reality could be achieved even if the two disciplines were not integrated. 
I.-C. MAGDAȘ, M. E. DULAMĂ, O.-R. ILOVAN, I.C. CRIȘAN

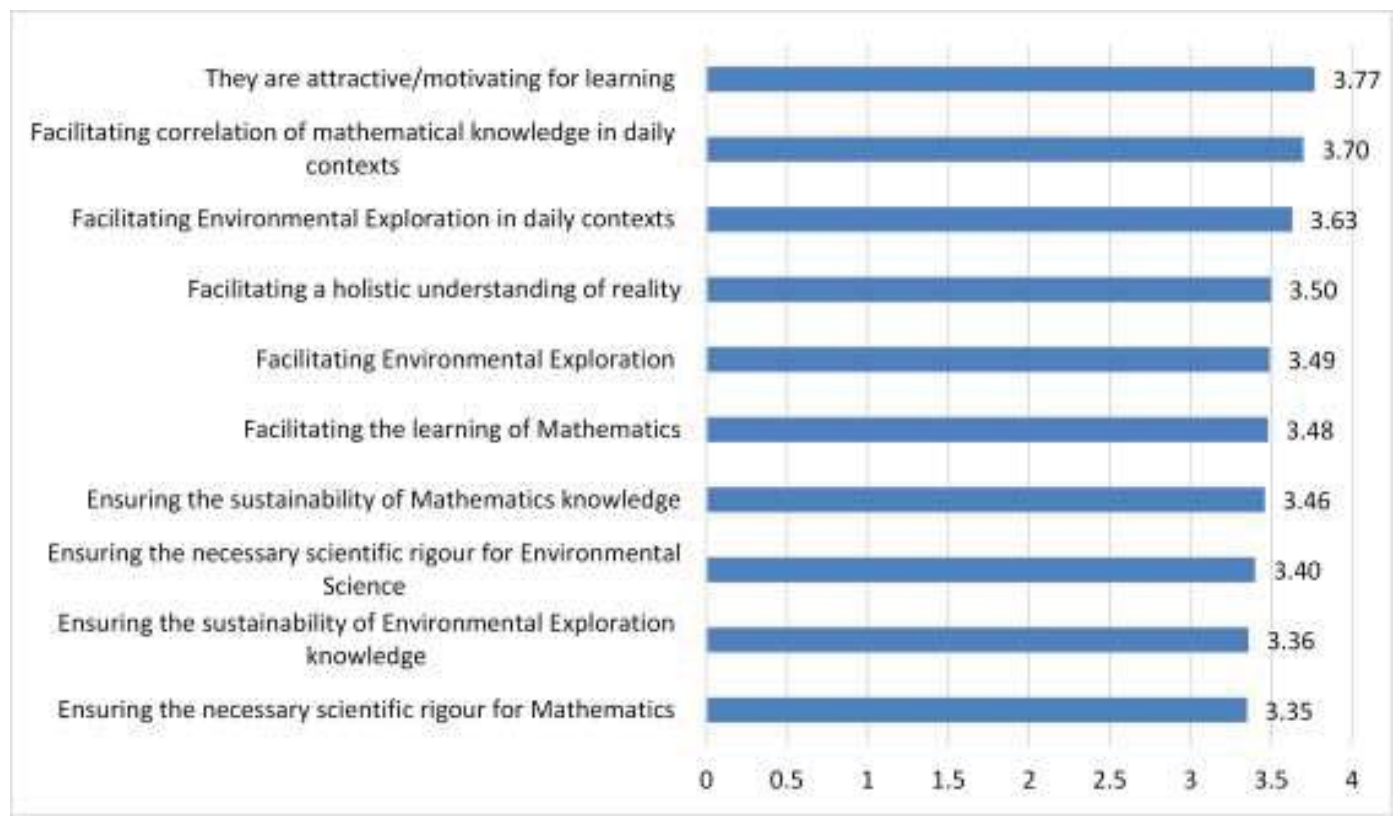

Fig. 7. Benefits due to MEE integration

In the hierarchy of limitations, of the disadvantages of the MEE study or of the problems determined by this approach (Figure 8), the teachers' perception of the lack of supporting materials relevant to the study of this integrated discipline was the first. The second problem correctly identified by teachers was that about learning Mathematics, which required specific lessons with Mathematics content. This kind of lessons allows fixing mathematical content in an intradisciplinary context, and the interdisciplinary connections can be realised either in the introduction phase of the concept or in the extension phase (Dulamă and Magdaş, 2014, fig. 1 ). The need for introducing lessons regarding Environmental Exploration was on the fourth place, so teachers felt the necessity to have lessons with specific content from that field. The two identified problems were naturally correlated with the difficulty of structuring knowledge both in Mathematics and in Environmental Exploration, indicators with scores above average of 3.18 and 3.13 respectively. Another problem considered by the teachers was the design of the thematic units and lessons, which again indicated the lack of methodologies and support materials, needs expressed by teachers in other studies (Magdaş et al., 2017). 


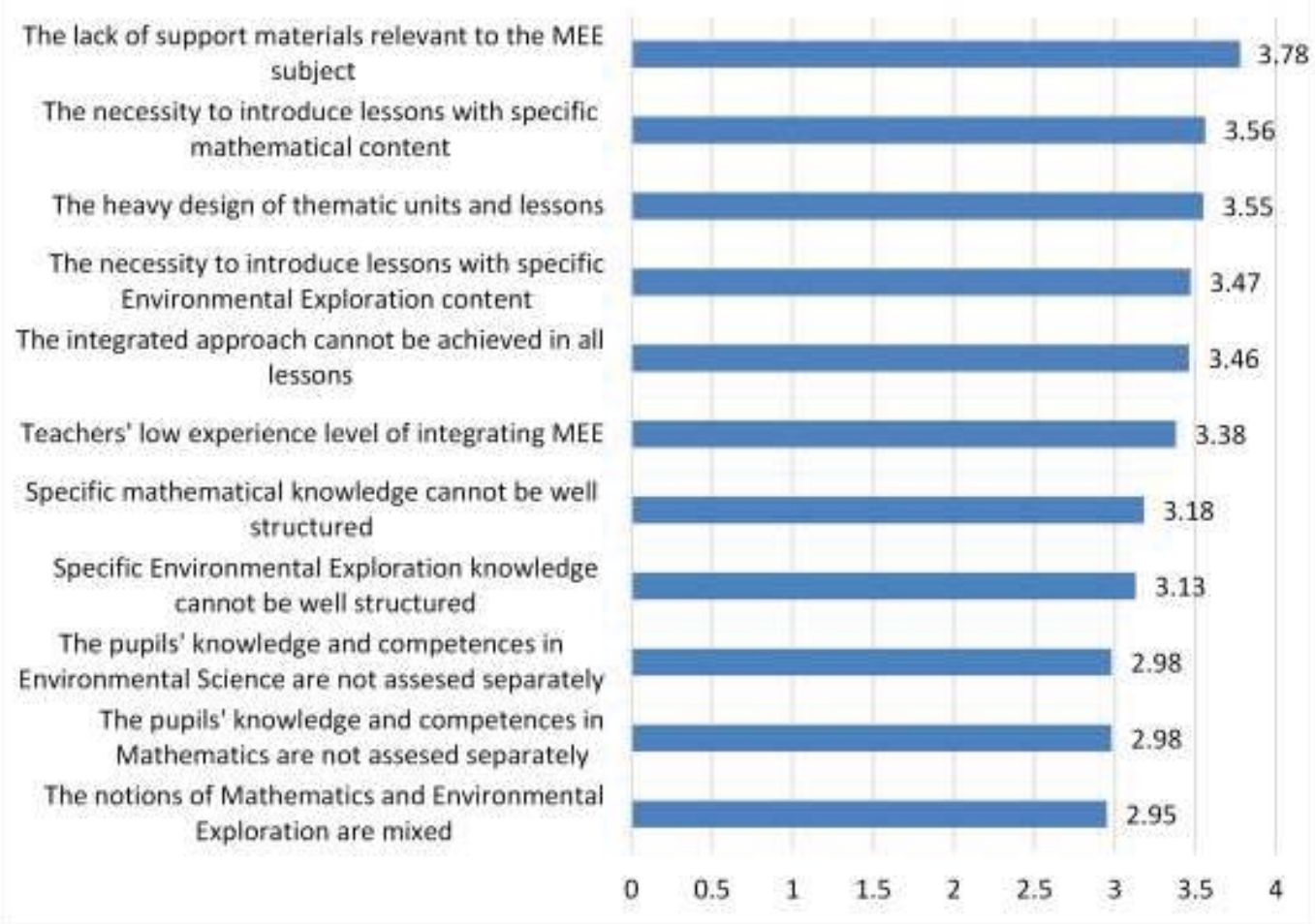

Fig. 8. Limitations, disadvantages or problems of MEE integrated study

\section{CONCLUSIONS}

Due to the introduction, in 2013, into the new Framework Plan for the Primary Education of the integrated Mathematics and Environmental Exploration (MEE) subject, of new textbooks and auxiliaries, we considered it necessary to find teachers' opinions about the way in which the curriculum documents facilitated the study of the MEE subject.

Through the responses to the questionnaire, we identified several important issues. Regarding teachers' sources of documentation, we found out that they prefered online sources (e.g. websites, blogs) and specialised forums. This is surprising because these sources are not reliable (in what the the correctness of the information is concerned). Only on the next places were placed the official documents or those elaborated by specialists. Teachers assigned scores of about 4 (out of a maximum of 5) to the clarity of all components of the school curriculum. In terms of textbooks and auxiliaries, respondents scored better auxiliaries across all the indicators considered.

The biggest benefit of introducing the MEE subject identified by respondents was that activities were more attractive / motivating for 
learning. At the opposite end, the smallest benefits related to ensuring the rigour and learning durability of both Mathematics and Environmental Exploration. Regarding the limitations, disadvantages or problems of studying the MEE subject, the lack of support materials was the first reported by the respondents. On the next places, they placed the need for specific lessons with mathematical content or the heavy design of thematic units and lessons.

These findings complement the ones presented by Magdaş et al. (2017) and give us an overview of the primary education teachers' perceptions about the challenges faced by them through introducing the new Framework Plan. Even after a timeframe of four years after its introduction, we find that teachers still need support and support materials for a better development of the didactic act.

\section{References}

Dulamă, M.E., \& Magdaș, I.-C. (2014). Analysing the Competences and Contents of "Mathematics and Environmental Exploration" Subject Curriculum for Preparatory Grade. Acta Didactica Napocensia, 7(2), 11-24.

Dulamă, M.E. (2011). Geografie şi didactica geografiei pentru învăţământul primar şi preşcolar. Cluj-Napoca: Presa Universitară Clujeană.

Dulamă, M.E. (2012). Ştiinţe şi didactica ştiinţelor pentru învăţământul primar şi preşcolar. Cluj-Napoca: Presa Universitară Clujeană.

Dulamă, M.E., Ilovan, O.-R., \& Maroşi, Z. (2015). Assessing University Students' Competences for Didactic Planning in "Mathematics and Environmental Exploration". Romanian Review of Geographical Education, 4(2), 77-87.

Magdaș, I.-C., \& Drângu, M.C. (2016). Primary School Teachers' Opinion on Digital Textbooks. Acta Didactica Napocensia, 9(3), 47-54.

Magdaș, I.-C. (2014). Didactica matematicii pentru învał̧ământul primar și pres,colar: actualitate și perspective. Cluj-Napoca: Presa Universitară Clujeană.

Magdaș, I.-C., Dulamă, M.E., Ilovan, O.-R., \& Crișan, I.C. (2017). The Training of Primary School Teachers for Teaching the MEE Subject. Proceedings of ERD Conference 2017 - under print.

Ministerul Educaţiei Naţionale (MEN) (2013). Programa şcolară pentru disciplina Matematica şi explorarea mediului, clasa a II-a. Bucharest.

Ministerul Educaţiei, Cercetării, Tineretului și Sportului (MECTS) (2012). Planulcadru de învățământ pentru învățământul primar, Ciclul achizițiilor fundamentale - clasa pregătitoare, clasa I și clasa a II-a. www.edums.ro/Legislatieinv\%20primar\%20p|\%20cadru.pdf. 